\title{
Metabolism and Excretion of Exogenous \\ Thyrotropin-Releasing Hormone in Humans
}

\author{
RAHIM M. BASSIRI and Robert D. Utiger \\ From the Endocrine Section, Department of Medicine, University of \\ Pennsylvania School of Medicine, Philadelphia, Pennsylvania 19104
}

A B S T R A C T To study the metabolism of thyrotropinreleasing hormone $(\mathrm{TRH})$ in vivo, $400 \mu \mathrm{g} \mathrm{TRH}$ was administered intravenously to eight normal male subjects. Multiple plasma and urine samples were obtained before and after TRH administration. Serum TSH concentrations increased after TRH administration in all subjects. Plasma TRH levels, measured by radioimmunoassay, were undetectable $(<0.4 \mathrm{ng} / \mathrm{ml})$ before TRH administration. Plasma TRH concentrations averaged $33 \pm 7 \mathrm{ng} / \mathrm{ml}$ (mean $\pm \mathrm{SEM}$ ) 2 min after $\mathrm{TRH}$ injection. Thereafter, they decreased rapidly so that the mean plasma TRH level was $2.9 \mathrm{ng} / \mathrm{ml} 20 \mathrm{~min}$ after $\mathrm{TRH}$ administration. The fall in plasma TRH levels was linear during this interval. Thereafter $\mathrm{TRH}$ levels declined more slowly. The mean half-life $\left(t_{\frac{1}{2}}\right)$ of TRH was $5.3 \pm 0.5 \mathrm{~min}$. The mean distribution volume was 15.7 \pm 3.8 liters, an average of $16.5 \%$ of body weight in these subjects. In the urine, $5.5 \pm 0.9 \%$ of the administered $\mathrm{TRH}$ was recovered in the $3 \mathrm{~h}$ after TRH administration. Of the total urinary TRH recovered, $84.9 \%$ was excreted in the first $30 \mathrm{~min}$. These results indicate that TRH is distributed in a large volume, that it is rapidly metabolized and that a significant quantity of administered TRH is excreted in the urine.

\section{INTRODUCTION}

The administration of thyrotropin-releasing hormone (TRH $)^{1}$ to normal subjects is followed by a prompt increase in serum thyrotropin (TSH) concentrations. Peak TSH levels are found $20-30 \mathrm{~min}$ after TRH administration and they then decline rapidly $(1,2)$. These results, plus the observations that $\mathrm{TRH}$ is inactivated

Received for publication 21 November 1972 and in revised form 12 January 1973.

${ }^{1}$ Abbreviations used in this paper: BAL, 2,3-dimercaptopropanol; TRH, thyrotropin-releasing hormone; TSH, serum thyrotropin concentrations. rapidly by human plasma or serum in vitro $(3,4)$, suggested that $\mathrm{TRH}$ rapidly disappears from the circulation in vivo. The present study was undertaken to determine the magnitude of plasma TRH concentrations that follow its intravenous administration and its rate of disappearance and metabolic fate.

\section{METHODS}

Study protocol. Eight normal male subjects $17-32$-yr old each received a bolus intravenous injection of $400 \mu \mathrm{g} \mathrm{TRH}$. None were receiving any medications. Six were normal weight and two were obese. None had any clinical evidence of thyroid disease, and all had normal serum $T_{4}, T_{3}$, and TSH concentrations (Table I). Blood was obtained for TSH and TRH determinations $-5,0,2,5,10,15,20,30,45,60$, 90 , and $120 \mathrm{~min}$ after TRH administration. 5-ml samples for TRH assay were collected in tubes containing heparin and $5.0 \mathrm{mg}$ 2,3-dimercaptopropanol (BAL). These samples were immediately placed in an ice bath and centrifuged within 2 min after collection for $5 \mathrm{~min}$ at $2^{\circ} \mathrm{C}$, and the plasma was frozen immediately. It previously has been shown (5), and further data is presented below, that BAL, in a concentration of $0.5 \mathrm{mg} / \mathrm{ml}$ plasma or higher, prevents TRH inactivation by serum at $37^{\circ} \mathrm{C}$ for at least $1 \mathrm{hr}$. Urine samples were collected for $60-120 \mathrm{~min}$ before and at $30-60-\mathrm{min}$ intervals for $3 \mathrm{~h}$ after TRH administration. Immediately after collection of urine the volume was measured, and a portion was frozen.

Measurements. Serum $\mathrm{TSH}$ and $\mathrm{T}_{3}$ concentrations were measured by radioimmunoassay $(6,7)$, and thyroxine was assessed by competitive protein-binding analysis (8). Plasma and urine TRH was measured by a sensitive and specific radioimmunoassay (9), all samples from an individual subject being assayed at the same time. The assay sensitivity at the time of these studies was $10 \mathrm{pg}$. Plasma samples were assayed in $10-$ and $25-\mu 1$ volumes since control plasma samples containing $1 \mathrm{mg} / \mathrm{ml} \mathrm{BAL}$ assayed in these volumes contained no detectable TRH $(<0.4 \mathrm{ng} / \mathrm{ml})$. Larger plasma volumes containing this concentration of BAL nonspecifically inhibited binding of $\left[{ }^{125} \mathrm{I}\right] \mathrm{TRH}$ by anti-TRH serum. Recovery of TRH $(10 \mathrm{ng} / \mathrm{ml})$ added to 10 plasma samples containing 1 $\mathrm{mg} / \mathrm{ml} \mathrm{BAL}$ and incubated at $37^{\circ} \mathrm{C}$ for $1 \mathrm{~h}$ was $101.2 \pm 1.7 \%$ (SEM).

The slope of the TRH disappearance line was calculated by the method of least squares, and the half time of disap- 
TABLE I

Experimental Subjects

\begin{tabular}{lcccccr}
\hline Subject & Age & Weight & $\begin{array}{c}\text { Serum } \\
\text { T. }\end{array}$ & $\begin{array}{c}\text { Serum } \\
\mathrm{T}_{3}\end{array}$ & $\begin{array}{c}\text { Serum } \\
\text { TSH }\end{array}$ & $\begin{array}{r}\text { Max } \Delta \\
\mathrm{TSH}^{*}\end{array}$ \\
\hline & $y r$ & $k g$ & $\mu g / 100 m l$ & $n g / 100 m l$ & $\mu U / m l$ & $\mu U / m l$ \\
R. Y. & 23 & 57.1 & 6.6 & 78 & $<2.0$ & 4.0 \\
D. B. & 24 & 84.3 & 5.0 & 68 & 3.6 & 13.3 \\
B. F. & 23 & 66.6 & 6.0 & 90 & 2.0 & 11.3 \\
T. T. & 23 & 60.0 & 7.6 & 98 & $<2.0$ & 11.6 \\
D. L. & 25 & 74.3 & 5.6 & 68 & $<2.0$ & 7.1 \\
G. B. & 27 & 76.2 & 8.7 & 98 & 3.6 & 13.0 \\
W. F. & 17 & 151.9 & 10.0 & 78 & 5.7 & 16.0 \\
T. H. & 32 & 160.2 & 6.0 & 74 & 3.2 & 19.8 \\
& & & & & & \\
\hline
\end{tabular}

* Maximum increase in serum TSH after TRH.

$T_{3}$, triiodothyronine; $T_{4}$, thyroxine.

pearance was calculated directly from the slope. The fractional turnover rate was calculated from the formula $\kappa=$ $0.693 / \mathrm{t}_{3} \times 100$. The zero time plasma TRH concentration was estimated by extrapolation of the disappearance line to zero time. From this, the volume of distribution was calculated (TRH administered/zero time TRH concentration).

The results of extensive studies of the serum inactivation of TRH immunological activity have been reported from this laboratory (4). However, most of these studies were done using a large quantity of TRH $(2 \mu \mathrm{g} / \mathrm{ml}$ serum $)$. When the plasma TRH results described herein became available, $\mathrm{TRH}$, in a concentration $(40 \mathrm{ng} / \mathrm{ml})$ near that calculated at zero time (Table II), was added to eight normal plasma samples and portions were removed after varying intervals of incubation at $37^{\circ} \mathrm{C}$. These portions were diluted 10 -fold with $0.25 \%$ bovine serum albumin (BSA), $0.01 \mathrm{M} \mathrm{PO}_{4}$, $0.15 \mathrm{M} \mathrm{NaCl}, \mathrm{pH} 7.5$, and their TRH content determined. The calculated rate of disappearance of this quantity of $\mathrm{TRH}$ in vitro was $4.1 \% / \mathrm{min}$, a value similar to that previously found in experiments in which the added $\mathrm{TRH}$ concentration was $2 \mu \mathrm{g} / \mathrm{ml}(6.2 \% / \mathrm{min})(4)$.

The effect of urine on TRH immun slogical activity was determined by incubation of TRH $(20 \mathrm{ng} / \mathrm{ml})$ in portions of fresh urine from five normal human subjects at 4,22 , and $37^{\circ} \mathrm{C}$. Portions were removed for imnunoassay before and

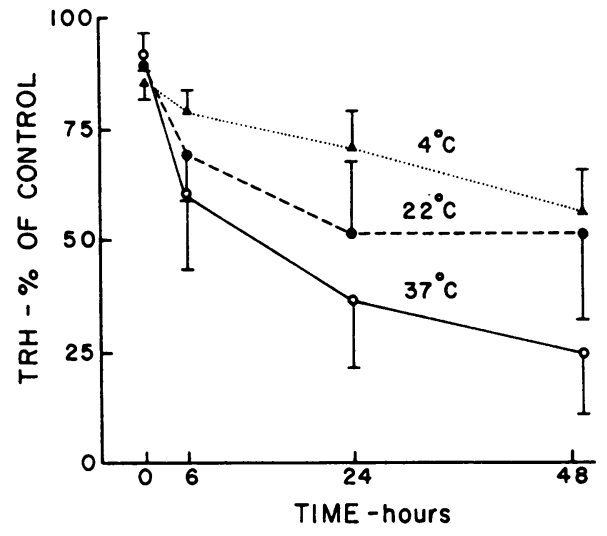

FIGURE 1 The effect of urine on TRH immunological activity. Urine containing $20 \mathrm{ng} / \mathrm{ml} \mathrm{TRH}$ was incubated at the temperatures indicated and portions removed for TRH assay after varying intervals of incubation. Vertical bars indicate \pm 1 SEM.

after 6,24 , and $48 \mathrm{~h}$ of ircubation. As shown in Fig. 1, significant TRH loss occurred after $6 \mathrm{~h}$ of incubation at 22 and $37^{\circ} \mathrm{C}$, but not at $4^{\circ} \mathrm{C}$. After 24 and $48 \mathrm{~h}$ of incubation at all three temperatures, TRH recovery progressively declined. Because of these results, urine samples from subjects receiving TRH were not modified, though they were frozen as rapidly as possible after collection. Since some randomly collected urine samples in doses of 50-200 $\mu$ l nonspecifically inhibited the TRH assay, all urine samples were assayed in sinaller quantities. In the urine samples collected from 0 to 31 and 30 to $60 \mathrm{~min}$ after TRH administration, extensive dilition was needed for quantitation of urinary TRH.

\section{RESULTS}

TRH was readily demonstrable in plasma 2 min after intravenous TRH administration. Thereafter the plasma TRH concentrations declined rapidly (Fig. 2). The mean plasma TRH level was $.33 \mathrm{ng} / \mathrm{ml} 2$ min after TRH

TABLE II

Plasma TRH Disappearance and Urine TRH Recovery Results

\begin{tabular}{lccccccc}
\hline Subject & $\begin{array}{c}\text { Plasma } \\
\text { TRH } 0^{*}\end{array}$ & $\mathrm{t}_{3}$ & $\mathrm{~K}_{\mathrm{TRH}}$ & Dist. vol. & Body wt & $\begin{array}{c}\text { Urine TRH } \\
\text { recovered }\end{array}$ & $\begin{array}{c}\text { Urine TRH } \\
\text { recovered }\end{array}$ \\
& $n g / m l$ & $\min$ & $\% / \min$ & luter & $\%$ & $\mu g$ & $\%$ dose \\
R. Y. & 33 & 8.6 & 8.1 & 12.0 & 21.0 & 25.6 & 6.4 \\
D. B. & 24 & 4.4 & 15.8 & 16.4 & 19.4 & 18.2 & 4.5 \\
B. F. & 41 & 4.4 & 15.8 & 9.8 & 14.7 & 36.9 & 9.2 \\
T. T. & 62 & 5.2 & 13.3 & 6.4 & 10.6 & 10.3 & 2.6 \\
D. L. & 45 & 5.1 & 13.6 & 8.8 & 11.8 & 31.5 & 7.9 \\
G. B. & 61 & 3.9 & 17.7 & 13.2 & 17.3 & 15.6 & 3.9 \\
W. F. & 21 & 5.1 & 13.6 & 18.6 & 12.2 & $-\ddagger$ & - \\
T. H. & 10 & 6.2 & 11.2 & 40.4 & 25.2 & 15.1 & 3.8 \\
Mean & 37 & 5.3 & 13.1 & 15.7 & 16.5 & 21.9 & 5.5 \\
SEM & 7 & 0.5 & 1.4 & 3.8 & 1.8 & 3.6 & 0.9 \\
\hline
\end{tabular}

* Calculated plasma TRH concentration at zero time.

$\ddagger$ Urine not collected. 


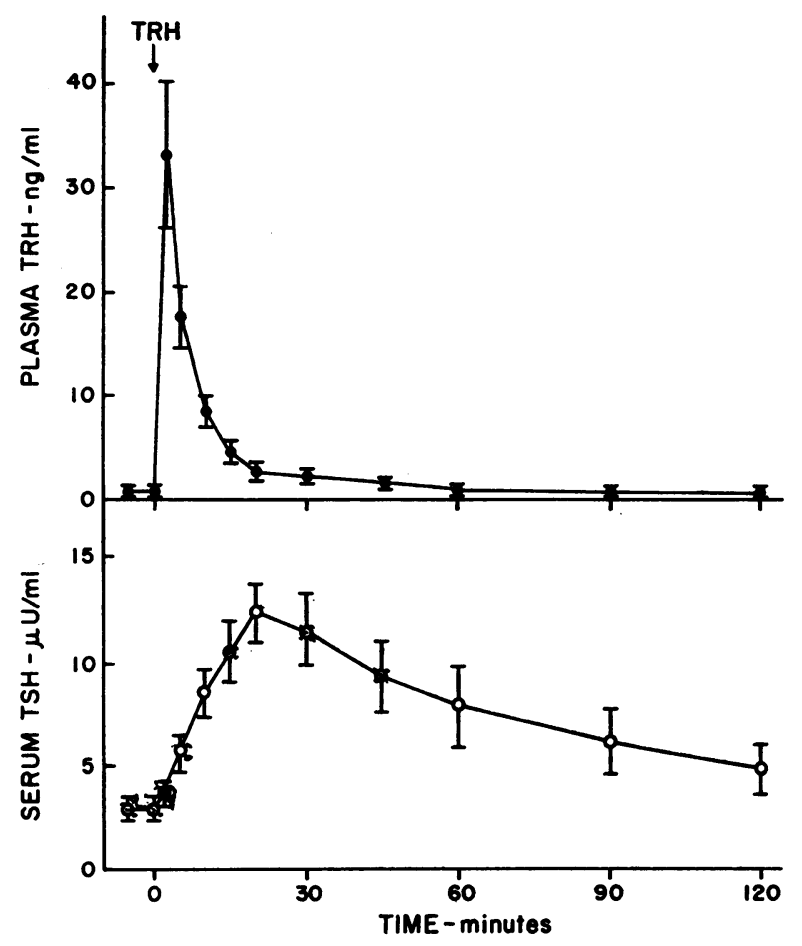

Figure 2 Mean plasma TRH (top) and serum TSH (bottom) concentrations after TRH administration in eight normal males. The vertical bars indicate \pm 1 SEM.

injection, and it had fallen to $2.9 \mathrm{ng} / \mathrm{ml} 20 \mathrm{~min}$ after TRH injection. Thereafter the rate of decline was slower. The values found at 60,90 , and $120 \mathrm{~min}$ after $\mathrm{TRH}$ injection were all $<1 \mathrm{ng} / \mathrm{ml}$. The increases in serum TSH concentrations, which occurred in all subjects and were, with one exception (R. Y.), within the range of normal previously reported from this laboratory for males in this age group (2), are shown at the bottom of this figure. There was no correlation between the peak plasma TRH and peak serum TSH concentrations. When the mean plasma TRH levels were plotted semilogarithmically (Fig. 3), the fall in plasma TRH appeared linear during the $2-20 \mathrm{~min}$ time interval. Therefore, the plasma TRH results obtained in this interval were used for the estimation of $t_{t}$. The results of the individual $t_{1}$, fractional turnover rate and distribution volume calculations are shown in Table II. The mean t 3 was $5.3 \pm 0.5 \mathrm{~min}$ (mean $\pm \mathrm{SEM}$ ) and the mean rate of disappearance $13.1 \% / \mathrm{min}$. The mean volume of distribution was $15.7 \pm 3.8$ liters, representing $16.5 \%$ of body weight.

TRH was not found in any of the urine samples collected before TRH administration. After TRH injection, TRH was readily detected in urine for $90 \mathrm{~min}$, most being found in the first $30 \mathrm{~min}$ (Fig. 4). The overall recovery averaged $21.9 \mu \mathrm{g}$ or $5.5 \%$ of the administered dose. Of this, an average of $18.6 \mu \mathrm{g}(84.9 \%$ of the re-

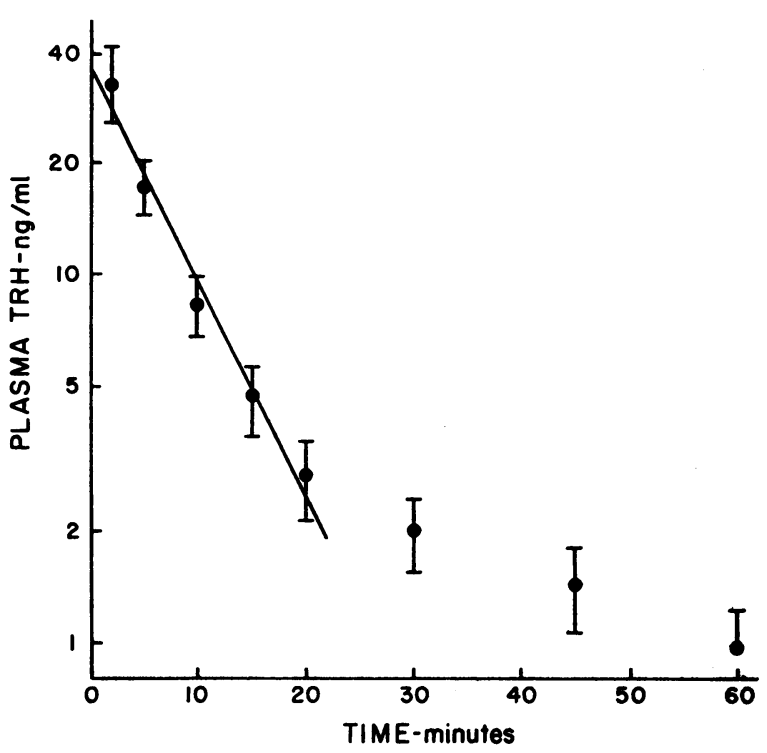

FIGURE 3 Semilogarithmic plot of disappearance of exogenously administered TRH. Vertical bars indicate \pm 1 SEM.

covered TRH) was excreted in the first 30 min and 2.6 $\mu \mathrm{g}(11.9 \%)$ during the second $30 \mathrm{~min}$ after TRH administration.

\section{DISCUSSION}

These studies demonstrate that TRH disappears from the circulation very rapidly, over $90 \%$ being removed within the first 20 min after intravenous TRH administration. The variability of the $t \frac{1}{2}$ results, from subject to subject, was not marked though in one obese subject (T. H.) low plasma TRH concentrations were found, which led to a high distribution volume estimate. The in vitro studies described suggest that the measured plasma and urine TRH concentrations were not artifactually reduced by inactivation of TRH after collection of the blood and urine samples. Thus, these results appear to give a true picture of the degradation of pharmacological quantities of TRH in man. In the only other report concerning TRH metabolism in human subjects, plasma

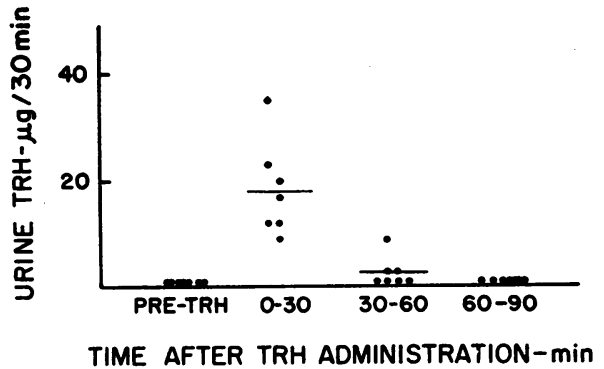

FIGURE 4 Urine TRH recovery after exogenous TRH administration. 
TRH (bioassay) levels averaged about $8 \mathrm{ng} / \mathrm{ml} 1 \mathrm{~min}$ and $5 \mathrm{ng} / \mathrm{ml} 5 \mathrm{~min}$ after injection of $200 \mu \mathrm{g} \mathrm{TRH}$ in five subjects and substantial quantities of TRH were found in urine in the $30 \mathrm{~min}$ after TRH administration (10).

Several limitations of this study are evident. The halflife data presented were obtained from plasma $\mathrm{TRH}$ measurements after the administration of pharmacological quantities of TRH. The rate of TRH degradation at normal plasma TRH concentrations, which are $<0.4$ $\mathrm{ng} / \mathrm{ml}$, may be considerably different. Since endogenous plasma TRH measurements are not available, the data herein reported cannot be used to estimate the size of the TRH pool or the TRH secretory rate. Secondly, in this study TRH was injected into an antecubital vein whereas normally it is secreted into the hypothalamic-hypophyseal portal system. It is likely that the dynamics of TRH metabolism, especially in regard to the effect of the hormone on its target gland the anterior pituitary, may be different after hypophyseal portal rather than peripheral venous entry.

The calculated volume of distribution of TRH averaged $16.5 \%$ of the body weight. This value corresponds closely with current estimates of extracellular fluid volume in normal human subjects (11). The finding of a large TRH distribution volume is not unexpected in view of the small molecular size of $\mathrm{TRH}$ and the lack of evidence for binding of TRH to plasma protein $(4,12)$. The distribution volume result further suggests that there is little early intracellular penetration of $\mathrm{TRH}$.

The rapid disappearance of TRH from plasma is undoubtedly a result of several metabolic processes. These include plasma and perhaps tissue destruction of TRH and renal excretion of TRH. TRH immunological activity is rapidly destroyed by incubation with plasma in vitro, and there is little reason to doubt the same occurs in vivo. The mean fractional rate of turnover of TRH in vivo, $13.1 \% / \mathrm{min}$, is roughly three times the rate of destruction of TRH by plasma in vitro. While it has been shown that homogenates of rat tissue destroy TRH biological and immunological activity (13, Bassiri and Utiger, unpublished observations), for reasons stated above it is unlikely that a substantial quantity of TRH enters cells. Administration of $\left[{ }^{14} \mathrm{C}\right] \mathrm{TRH}$ and $\left[{ }^{3} \mathrm{H}\right] \mathrm{TRH}$ to animals has been shown to result in tissue accumulation of radioactivity (tissue/plasma ratios $>1$ ) in anterior pituitary, liver, and kidney but this radioactivity was not identified as TRH per se (14). It is possible even this radioactivity is not intracellular, but rather bound to the cell surface.

In these normal subjects, renal excretion accounted for $5.5 \%$ of the administered TRH, most of which appeared in the first $30 \mathrm{~min}$ after TRH administration. Thus at high plasma TRH concentrations, TRH is rapidly cleared by the kidney. Whether or not substantial renal clear- ance occurs at endogenous TRH concentrations remains to be determined. In view of the rapid clearance of $\mathrm{TRH}$, and the minimal inactivation of $\mathrm{TRH}$ which occurs in urine, urine TRH measurements may be more feasible than those in plasma.

\section{ACKNOWLEDGMENTS}

The authors wish to thank Miss Kathleen Kelley and Mrs. Maryanne O'Neill for their expert technical assistance, Mrs. Elaine Paolini for secretarial support and Miss Cordelia Shute and her staff of the Clinical Research Center for their help with the clinical studies.

This work was supported by U. S. Public Health Service Grants T01 AM05649, R01 AM14039, and RR-40 (Clinical Research Center).

\section{REFERENCES}

1. Anderson, M. S., C. Y. Bowers, A. J. Kastin, D. S. Schalch, A. V. Schally, P. J. Snyder, R. D. Utiger, J. F. Wilber, and A. J. Wise. 1971. Synthetic thyrotropin-releasing hormone: a potent stimulator of thyrotropin secretion in man. N. Engl. J. Med. 285: 1279.

2. Snyder, P. J., and R. D. Utiger. 1972. Response to thyrotropin releasing hormone (TRH) in normal man. J. Clin. Endocrinol. Metab. 34 : 380.

3. Nair, R. M. G., T. W. Redding, and A. V. Schally. 1971. Site of inactivation of thyrotropin-releasing hormone by human plasma. Biochemistry. 10: 3621 .

4. Bassiri, R., and R. D. Utiger. 1972. Serum inactivation of the immunological and biological activity of thyrotropin-releasing hormone (TRH). Endocrinology. 91: 657.

5. Bassiri, R., and R. D. Utiger. 1972. Thyrotropin releasing hormone radioimmunoassay. Serono Foundation Conference on Hypothalamic Hypophysiotropic Hormones. In press.

6. Odell, W. D., J. F. Wilber, and R. D. Utiger. 1967. Studies of thyrotropin physiology by means of radioimmunoassay. Recent Prog. Horm. Res. 23: 47.

7. Lieblich, J. M., and R. D. Utiger. 1972. Triiodothyronine radioimmunoassay. J. Clin. Invest. 51: 157.

8. Murphy, B. E. P., and C. J. Pattee. 1964. Determination of thyroxine utilizing the property of protein-binding. J. Clin. Endocrinol. Metab. 24: 187.

9. Bassiri, R., and R. D. Utiger. 1972. The preparation and specificity of antibody to thyrotropin releasing hormone. Endocrinology. 90: 67.

10. Leppäluoto, J., P. Virkkunen, and H. Lybeck. 1972. Elimination of TRH in man. J. Clin. Endocrinol. Metab. 35: 477 .

11. Edelman, I. S., and J. Liebman. 1959. Anatomy of body water and electrolytes. Am. J. Med. 27: 256.

12. Vale, W. W., R. Burgus, T. F. Dunn, and R. Guillemin. 1971. In vitro plasma inactivation of thyrotropin releasing factor (TRF) and related peptides. Its inhibition by various means and by the synthetic dipeptide PCA-His-OME. Hormones (Basel). 2: 193.

13. Redding, T. W., and A. V. Schally. 1969. Studies on the inactivation of thyrotropin-releasing hormone (TRH). Proc. Soc. Exp. Biol. Med. 131: 415.

14. Redding, T. W., and A. V. Schally. 1971. The distribution of radioactivity following the administration of labeled thyrotropin-releasing hormone $(\mathrm{TRH})$ in rats and mice. Endocrinology. 89: 1075.

TRH Degradation and Excretion

1619 